\title{
寄生的離散ウェーブレット变換および产の異常信号検出への応用*
}

章*1, 池内宏 樹*2, 斎木典保*2
今村孝*1, 石井秀明*3
戸田 浩*2, 三宅哲夫*2

\section{Parasitic Discrete Wavelet Transform and its Application on Abnormal Signal Detection}

\author{
Zhong ZHANG**4, Hiroki IKEUCHI, Noriho SAIKI, \\ Takashi IMAMURA, Hideaki ISHII, \\ Hiroshi TODA and Tetsuo MIYAKE \\ *4 Department of Production Systems Engineering, Toyohashi University of Technology, \\ 1-1 Hibarigaoka, Tempaku-cho. Toyohashi-shi, Aichi, 441-8580 Japan
}

\begin{abstract}
In this study, in order to improve effectiveness of the abnormal signal detection, we first developed a novel parasitic discrete wavelet transform (P-DWT) to perform fast wavelet instantaneous correlation (F-WIC) and then proposed a new design method of the parasitic filters for the PDWT. Furthermore, we showed a judgment standard for assessing the credibility of the abnormal signal detection by using the P-DWT. Finally, we applied the F-WIC to car rattle noise source identification and showed that our method can improve computation efficiency and obtain sufficient calculation accuracy at the same time.
\end{abstract}

Key Words: Wavelet Transform, Abnormal Detection, Sound, Vibration, Time-Frequency Analy. sis

\section{1. ばめに}

周知のようにウェーブレット変換 (Wavelet transform, WT) は, 時間-周波数の解析平面上に信号の特徵を明 確に表現できるため, 非定常信号の解析に広く用いら れている(1)(2).WTではマザーウェーブレット (Mother wavelet, $\mathrm{MW})$ と呼ばれる単一の関数 $\psi(t)$ を, 拡大 $a$ と 平行移動 $b$ の変数により変形させた関数組 $\psi_{a, b}(t)$ によ り, 各周波数带域に適した解析を行うことが可能であ る. またこのWTは, 変数 $a$ と $b$ を連続变数とする連 続ウェーブレット変換 (Continuous wavelet transform, CWT) と, 離散変数とする離散ウェーブレット変換 (Discrete wavelet transform, DWT)に分けることがで きる. CWTにおいては，MW はアドミッシブル条件 (Admissibility condition) を満たしていればどのような 関数でも使える. しかし $\mathrm{MW}$ の選択は，時として困 難な場合がある。すすなわち末知の解析信号に対して, MWをどのように選択すればよいか，はっきりとした 選択基準はない，また非定常異常信号には通常，多数

* 原稿受付 2009 年 2 月 18 日

*1 正員, 豊橋技術科学大学工学部生産ス广ム工学系( 441 8580 豊橋市雲雀ケ 丘 $1-1$ )

*2 曹獢技術科学大学工学部生産ステム工学采.

*3 ジェイテクト(株) NV 技術部(㞼634-8555 㮒原市十市町 $333)$.

E-mail : zhang@is.pse.tut.ac.jp
の特徵成分が含まれており，その強さは様々で，かつ 発生時期は不規則である. そのためバンドパスフィル タの特性を有する通常の MWを用いた，異常信号の検 出や定量評価の実現には，技術上の様々な困難が伴う.

ところでCWTは一種の相似変換と考え，既知の異常 信号により作成した $\psi(t)$ から定義される $\psi_{a, b}(t)$ をス ケールとして解析信号 $f(t)$ を計り， $f(t)$ と $\psi_{a, b}(t)$ の相 似性をWT の係数 $w(a, b)$ で数值化できるる ${ }^{(3)}$. 著者らは この特街を生かし，異常信号による複素数実信号マザー ウェーブレット (Complex real-signal mother wavelet, $\mathrm{C}$ RMW) の構成法を提案し，それを用いた CWT から 得られたスケール $a=1$ のウェーブレット係数の絶 対值をウェーブレット瞬時相関 (Wavelet instantaneous correlation, WIC) と定義した ${ }^{(4)}$. さらに周波数特性が 変化する非定常な異常信号に対して, 多数の変動的 な晎常信号から平均的実信号マザーウェーブレット (Average real-signal mother wavelet, A-RMW) の構成手 法を提案し，A-RMW を用いた WIC を異常信号の定 量評価に応用してその有効性を確認した ${ }^{(5)}$. 以下，特 に強調しない限り、C-RMW や A-RMW 等を実信号マ ザーウェーブレット (RMW) と呼ぶことにする．とこ ろで RMW は理論上 CWT のみに利用が可能であるが, CWTには一般化された高速計算アルゴリズムが存在 しないため，さらなる計算速度の向上は困難である. 


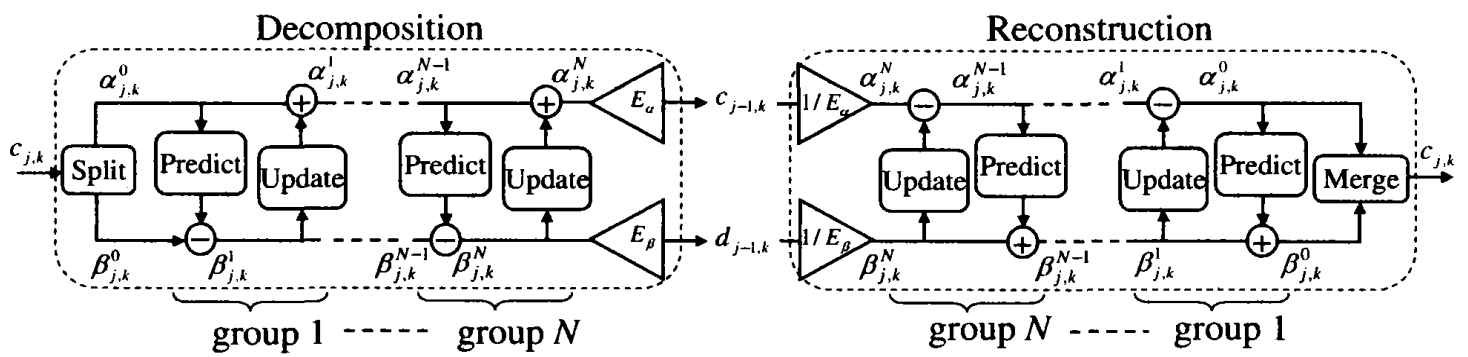

(a) The DWT by using the Lifting Scheme

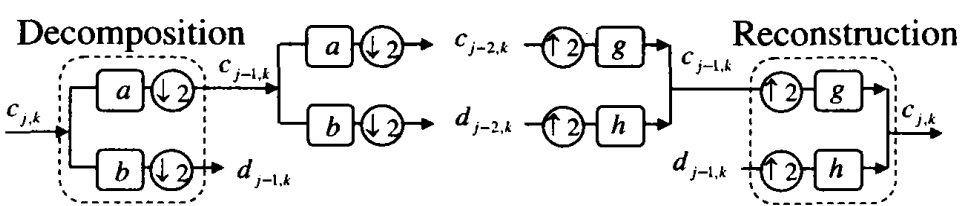

(b) The DWT by using Mallat's fast algorithm

Fig. 1 The Lifting scheme and Mallat's fast algorithm for the DWT

一方 DWT には Mallat ${ }^{(6)}$ の多重解像度解析 (MRA) における高速アルゴリズムと, Sweldens ${ }^{(7)}$ のフティ ングスキームによる高速計算アルゴリズムが存在する. もし実信号マザーウェーブレット (RMW) が DWT に 適用できれば，異常検出の高速化が可能である．とこ ろが DWT に適用される MW は，信号の再構成を保 証する (双) 直交条件を満たす必要があり，任意の異常 信号から構成される RMWに，この条件を課すことは 不可能である. 従って異常信号より設計された RMW を DWT の MW に適用することは非常に困難である.

本研究では, RMW に対応する DWT 用のフィルタ を設計し，それを従来の DWT に付与させることによ り，異常信号を高速に検出する手法を提案する．この RMW に対応するフィルタを奇生フィルタ，また寄生 フィルタが付けられた DWT を寄生的離散ウェーブレッ 卜変換 (Parasitic discrete wavelet transform, P-DWT) と 呼ぶことにする. そして車の異常音源探査に P-DWT を適用し, 従来の CWTによる検出結果と比較して, その有用性を確認する。

\section{CWTによるウェーブレット瞬時相関の吟味}

有限なエネルギーを持つ時系列信号 $f(t)$ のCWT は

$$
w(a, b)=a^{-1 / 2} \int_{-\infty}^{\infty} f(t) \overline{\psi\left(\frac{t-b}{a}\right)} d t
$$

と定義される ${ }^{(2)}$.ここで $a(a>0)$ はスケール，1/a は 周波数に対応し, $b$ は時刻のパラメータである. なお， $\overline{\psi(t)}$ は $\psi(t)$ の複素共役である. 関数 $\psi(t)$ は MW と呼 ばれ，通常アドミッシブル条件 (admissibility condition) を満たさなければならない.しかし $\psi(t)$ が遠方で充 分速く零になる場合には，次のような条件を満足すれ ば, 実用上, 問題ないことがわかっている(4)(5).

$$
\int_{-\infty}^{\infty} \psi(t) d t=0
$$

この意味で, MW の選択範囲は広く, その構成も DWT の場合より簡単である.

また, 式(1)からわかるように, CWT は時間 $b$ と 周波数 $1 / a$ の 2 次元の平面上で非定常信号の特徵が 解析できる.ところが，第 1 章で述べたようにバンド パスフィルタの特性を有する通常の MW を用いた異 常信号の検出と定量評価には，様々な困難が伴う．著 者らは，これらの困難を克服するために異常信号から 実信号マザーウェーブレット RMW を構成し，それを 用いたCWTより得られた，スケール $a=1$ における $|w(1, b)|$ を，ウェーブレット瞬時相関 (WIC) $R(b)$ と定 義した ${ }^{(4)(5)}$.

$$
R(b)=|w(1, b)|
$$

なお RMW の構成手順は次のとおりである.1) 異常信 号から特幑的な部分を切り出し, 遠方で充分速く零に なるような空関数を掛け, 次に平均值を差し引くこと により $\mathrm{DC}$ 成分を取り除き，実数型 $\mathrm{RMW} \psi^{R}(t)$ を構 成する. 2) ノルム $\| \psi^{R}||$ が 1 となるように正規化する.

$$
\left\|\psi^{R}\right\|=\left[\int_{-\infty}^{\infty}\left|\psi^{R}(t)\right|^{2} d t\right]^{1 / 2}=1
$$

3) $\psi^{R}(t)$ をフーリエ変換し周波数スペクトル $\hat{\psi}^{R}(f)$ を 得る. 4) 周波数領域 $f \leq 0$ に扔いて $\hat{\psi}^{R}(f)$ をゼロとし, また $f>0$ においては $\hat{\psi}^{R}(f)=2 \hat{\psi}^{R}(f)$ とする. 5)ここ で $\hat{\psi}(f)$ の実数部を $\hat{\psi}_{r}(f)$, 虚数部を $\hat{\psi}_{i}(f)$ で表すこと にして, $\hat{\psi}_{r}(f)=\sqrt{\left(\hat{\psi}_{r}^{R}(f)\right)^{2}+\left(\hat{\psi}_{i}^{R}(f)\right)^{2}}$ ままた $\hat{\psi}_{i}(f)$ は ゼロとし, 全周波数成分の位相情報を削除する処理を 行う. 6) 逆フーリエ変換により $\psi(t)=\psi_{r}(t)+i \psi_{i}(t)$ が 得られる.このように構成された RMW の実数部 $\psi_{r}(t)$, 虚数部 $\psi_{i}(t)$ は対称性を有する複素数型 RMW であり, 対称的複素数型 RMW(Symmetric complex real-signal mother wavelet, SC-RMW) と呼ぶ. 7)さらに2つ, ま 
たはそれ以上の SC-RMW を加算し，正規化したもの を平均的 RMW(A-RMW) と呼ぶ. 文献 (5)では上述の RMW の詳細を紹介し，さらに RMW を用いた WIC が異常信号検出に有用であることを確認している.

\section{3. リフティングスキームによる DWT}

図 1(a)kは Sweldens ${ }^{(7)}$ のリフティングスキームに よるDWT の高速計算法のアルゴリズムを示す．また 比較のために, 図 1(b)には Mallat ${ }^{(6)}$ の多重解像度解析 (MRA)による高速アルゴリズムも示している. 図 1(a) のリフティングスキームによる分解計算における破線 に囲まれた部分の動作は, 図 1(b) の Mallat の高速ア ルゴリズムによる破線に囲まれた部分と同等であるが, その計算法は Mallatのものとは異なり, ダウンサンプ リングを先に行い，その後にフィルタ処理を行う.な 打図 1(a)に扔ける分解計算の各モジュールの处理は以 下の通りである.

1. Split：入力信号 $\left\{c_{j, k}\right\}$ を偶数列 $\left\{\alpha_{j, k}^{0}\right\}$, 奇数列 $\left\{\beta_{j, k}^{0}\right\}$ に分解する.

$$
\alpha_{j, k}^{0}=c_{j, 2 k}, \quad \beta_{j, k}^{0}=c_{j, 2 k+1}
$$

2. Predict：偶数列 $\left\{\alpha_{j, k}^{n-1}\right\} \quad(n=1,2, \cdots, N$, ただし $N>0$ ：整数）を用いて奇数列を更新する.

$$
\beta_{j, k}^{n}=\beta_{j, k}^{n-1}-\sum_{l} s_{l}^{p_{n}} \alpha_{j, k-l}^{n-1}, \quad n=1,2, \cdots, N
$$

ただし数列 $\left\{s_{k}^{p_{n}}\right\}$ は $n$ 組目の Predict フィルタで ある.

3. Update : 奇数列 $\left\{\beta_{j, k}^{n}\right\}$ を用いて偶数列を更新する.

$$
\alpha_{j, k}^{n}=\alpha_{j, k}^{n-1}+\sum_{l} s_{l}^{u_{n}} \beta_{j, k-l}^{n}, \quad n=1,2, \cdots, N
$$

ただし数列 $\left\{s_{k}^{u_{n}}\right\}$ は $n$ 組目の Update フィルタで ある. なお Predict フィルタと Update フィルタは, 図1(a)に掲げたように, 通常, 複数組により構成 される（骬らかな形状の MW ほど組数が多い）。 すなわち,これらが $N$ 組 $(N>0$ : 整数) の場合, 上記の 2) と 3)の処理を, $n$ の值を 1 から $N$ まで 1 つずつ増加させ, $N$ 回ほど絽り返すことになる.

4. エネルギー正規化：上記の $N$ 回目の処理で得ら れた $\left\{\alpha_{j, k}^{N}\right\},\left\{\beta_{j, k}^{N}\right\}$ のエネルギーを正規化し, 以 下の $\left\{c_{j-1, k}\right\},\left\{d_{j-1, k}\right\}$ を得る.

$$
c_{j-1, k}=E_{\alpha} \alpha_{j, k}^{N}, \quad d_{j-1, k}=E_{\beta} \beta_{j, k}^{N}
$$

さらに図1(a)の分解計算を式(8)の $\left\{c_{j-1, k}\right\}$ に綝り返 し適用することで, 任意レベルまで計算可能である. 再構成の計算は分解計算の順番を逆にし, 演算子と フィルタも逆にして以下の計算を行う（ただし以下の
Table 1 Filter coefficients of Predict and Update

\begin{tabular}{|c|c|c|c|}
\hline $\mathrm{k}$ & -1 & 0 & 1 \\
\hline \hline$s_{k}^{p_{1}}$ & & 0.92593292 & \\
\hline$s_{k}^{u_{1}}$ & & 0.49852318 & 0.13192303 \\
\hline$s_{k}^{p_{2}}$ & 0.42932612 & 1.45211892 & \\
\hline$s_{k}^{u_{2}}$ & -0.30948300 & 0.28040238 & \\
\hline$s_{k}^{p_{3}}$ & & -1.9589167 & -0.7680659 \\
\hline$s_{k}^{u_{3}}$ & & -0.17264009 & \\
\hline \hline$E_{\beta}, E_{\alpha}$ & 2.03486147 & 0.49143394 & \\
\hline
\end{tabular}

2., 3. の処理は, $n$ の值を $N$ から 1 まで 1 つずつ減少 させ, $N$ 回ほど絽り返す).

1. エネルギーの調整：

$$
\alpha_{j, k}^{N}=c_{j-1, k} / E_{\alpha}, \quad \beta_{j, k}^{N}=d_{j-1, k} / E_{\beta}
$$

2. Update：偶数列の更新

$$
\alpha_{j, k}^{n-1}=\alpha_{j, k}^{n}-\sum_{l} s_{-l}^{u_{n}} \beta_{j, k+l}^{n}, \quad n=1,2, \cdots, N(10)
$$

3. Predict：奇数列の更新

$$
\beta_{j, k}^{n-1}=\beta_{j, k}^{n}+\sum_{l} s_{-l}^{p_{n}} \alpha_{j, k+l}^{n-1}, \quad n=1,2, \cdots, N
$$

4. Merge : 偶数列と奇数列から $\left\{c_{j, k}\right\}$ を再構成する.

$$
c_{j, k}=\left\{\begin{array}{ll}
c_{j, 2 l}=\alpha_{j, l}^{0}, & k=2 l \\
c_{j, 2 l+1}=\beta_{j, l}^{0}, & k=2 l+1
\end{array} \quad(l: \text { 整数 })(12)\right.
$$

表 1 には直交ウェーブレット Symlet $5^{(2)}$ に対応するリ フティングスキームの Predictフィルタと Update フィル タの例を示す ${ }^{(7)}$. 通常, Predict フィルタ, Update フィ ルタ等は, 設計者により公開されている. 表 1 のフィ ルタ係数を使用した, 任意信号に対するリフティング スキームは, Mallat の高速アルゴリズムによる DWT と同等の解析結果となるが, リフティングスキームの 演算ではダウンサンプリングの後にフィルタ処理を行 うため, 掛け算の数が半分以下となり, 高速化される. 本研究ではこの特徵を生かし DWT の計算にリフティ ングスキームを用いることにした。

\section{4. 新たな寄生的離散ウェーブレット变換の提案}

4.1 寄生的離散ウェーブレット変換の定義 第 1 章で述べたように，DWT に適用する MW は信号の 再構成を保証するため (双) 直交条件を満たさなけれ ばならない．しかし異常信号から構成された RMW は この条件を満たさず，そのままDWTに適用できない． 本研究では異常信号の検出と評価を目的とした, 異常 信号から構成された RMW に近似したフィルタを，通 


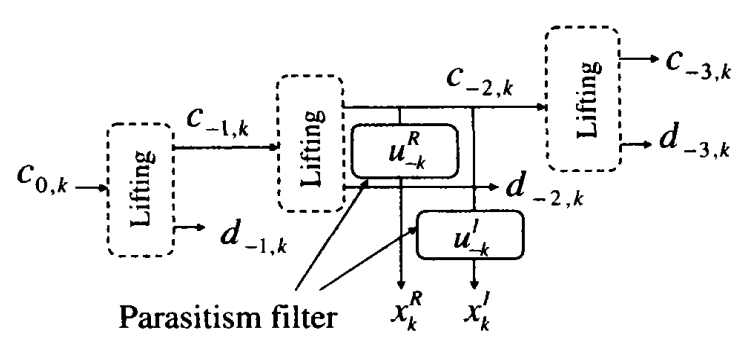

Fig. 2 Decomposition tree of the parasitic discrete wavelet transform (P-DWT) and the parasitic filters

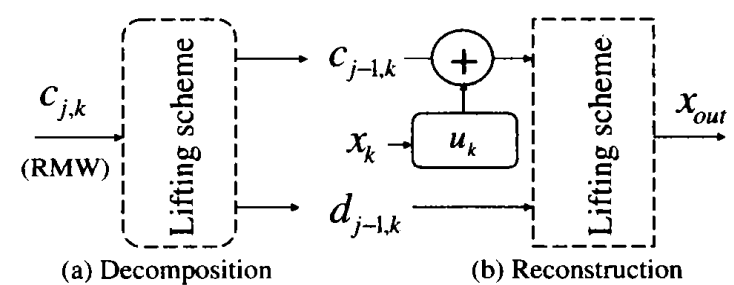

Fig. 3 Design method of the parasitic filters

常の DWT に付与させる新たな離散ウェーブレット変 換を提案する.この RMWに近似したフィルタを寄生 フィルタ，寄生フィルタが付けられた DWT を寄生的 離散ウェーブレット変換 (P-DWT) と呼ぶことにする.

図 2 には提案したP-DWT のッリー構造を示す. 図 中の破線に囲まれた部分は図 1(a)に示した (双) 直交の MW を用いるリフティングスキームによるDWT であ る. また RMW と区別するため，DWTに用いた MW をべース MW と呼ぶことにする. そして $c_{j, k}, d_{j, k}$ は DWTにより得られたウェーブレット係数 (高周波成分) とスケーリング係数 (低周波成分), $x_{k}^{R}, x_{k}^{l}$ は寄生フィ ルタにより検出される異常信号の実部と虚部であり, $\left\{u_{k}^{R}\right\},\left\{u_{k}^{I}\right\}$ はそれぞれ RMWに近似した需生フィルタ の実数部, 虚数部である. また寄生フィルタが付与さ れるレベルを寄生レベルと呼ぶことにする. 図 2 の例 では寄生レベルは -2 であるが, 異常信号の特性に応 じて他のレベルに，また複数の寄生フィルタを付与さ せることも可能である.

また図 2 と図 1(b) を比較してわかるように, P-DWT のツリー構造は寄生フィルタがなければ, 従来の DWT のツリー構造とまったく同じ構成となる. すなわち, P-DWT は従来 DWT に対し, 寄生フィルタを付与さ せて異常信号を検出するので, 寄生フィルタは DWT の計算には影響を与えない，また笴生フィルタにより 検出された異常信号を再構成する必要はないので，信 号の再構成を保証するための (双) 直交条件を満たす必 要はない，従って寄生フィルタの設計も簡単となる.

4 .2 寄生フィルタの設計 寄生フィルタは図 3 に示すツリー構造を利用して設計を行う. 設計の手順

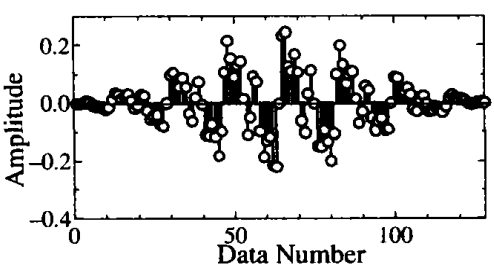

(a) Parasitic filter $\left\{u_{k}^{\prime}\right\}$

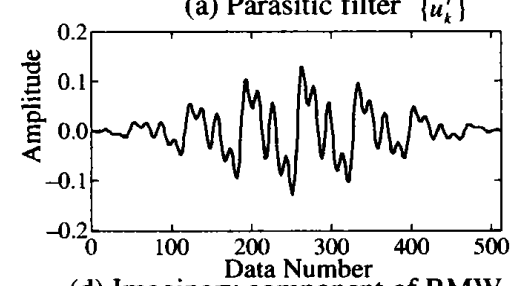

(d) Imaginary component of RMW

Fig. 4 Example of the designed parasitic filters

は以下のとおりである.

1. 第 2 章で示した手法で構成した RMW をDWTに 入力し寄生レベルまで分解する.

2. 寄生レベルで得られた係数 $c_{j-1, k}$ を寄生フィルタ の初期係数 $\left\{u_{k}\right\}$ にセットする.

3. 図 3 の再構成部を利用し, 入力信号を $c_{j-1, k}=0$, $d_{j-1, k}=0, x_{k}=\delta_{k, 0}$ (Kronecker delta) として逆変 換を行い再構成信号 $x_{\text {out }}$ を求める.

4. 評価関数 $\operatorname{argmin}|| x_{\text {out }}-R M W \|$ が最小になるよう に最適化手法により $\left\{u_{k}\right\}$ を更新し，RMW に最 適近似する寄生フィルタ $\left\{u_{k}\right\}$ が得られる.

また複素数 RMW $\psi(t)=\psi_{r}(t)+i \psi_{i}(t)$ の場合には， RMW の実数部および虚数部に対応する寄生フィルタ $\left\{u_{k}^{R}\right\},\left\{u_{k}^{I}\right\}$ を以上の手順に従って，それぞれ設計する 必要がある.

ここで，例として式(13)に示した $50[\mathrm{~Hz}], 100[\mathrm{~Hz}]$, $200[\mathrm{~Hz}]$ の 3 つの成分を有するモデル信号を用い,

$$
f(t)=\sin (100 \pi t)+0.7 \sin (200 \pi t)+0.7 \sin (400 \pi t)
$$

サンプリング周波数を $3500[\mathrm{~Hz}], \mathrm{RMW}$ の長さを 512 点にして第 2 章で示した手法で SC-RMW を構成した. そしてべース MW を Symlet5 として，この RMW を 寄生レベル -2 まで分解し, 上述の手順で寄生フィル タの設計を行った. 図 4(a) は RMW の虚数部を元に して設計した寄生フィルタ $\left\{u_{k}^{I}\right\}$ の例である. また比 較のため, RMW の虚数部の例を図 4(b) に示す.

さらに RMW $\psi(t)$ の周波数特性 $|\hat{\psi}(f)|, x_{\text {out }, k}^{R}$ と $x_{\text {out }, k}^{I}$ の周波数特性 $\left|X_{\text {out }}^{R}(f)+i X_{\text {out }}^{I}(f)\right|$ を求女, 図 5 に示す. また図 5 には寄生レベルにおける $c_{j, k}$ を得る ための分解フィルタ (ベース MW に対応) の周波数 特性 $|A(f)|$ も示している. 図示のように, $|\hat{\psi}(f)|$ と $\left|X_{\text {out }}^{R}(f)+i X_{\text {out }}^{I}(f)\right|$ はほぼ完全に重なっており，寄生 フィルタが RMW に良く近似していることが分かる. 


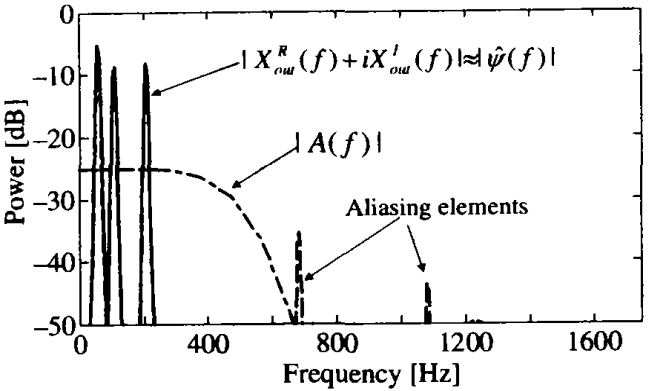

Fig. 5 Example of the frequency characteristics of the RMW $|\hat{\psi}(f)|$ and $\left\{X_{\text {out }}^{R}(f)+i X_{\text {out }}^{I}(f) \mid\right.$.

また $|A(f)|$ の周波数領域には $\left|X^{R}(f)+i X^{I}(f)\right|$ の周波 数成分が含まれているため, その中から寄生フィルタ $\left\{u_{k}^{R}\right\}$ と $\left\{u_{k}^{I}\right\} に よ り$ 異常信号の検出は可能であること がわかる.ここで, 図 5 において 650[Hz] と 1100[Hz] 付近に見られる成分は, 寄生フィルタの近似誤差の影 響で生じたエイリアシング成分であるが，その值は 50 $\sim 200[\mathrm{~Hz}]$ の主成分に比較して $-20[\mathrm{~dB}]$ 以下であり, 問題ないレベルである.

4 -3 寄生レベルの判定ＲMWに良好に近似す る寄生フィルタを得るために，寄生フィルタの設計前 に RMW の周波数成分が分解フィルタの周波数領域に 含まれるように寄生レベルを定める必要がある. 通常, 寄生フィルタが付与している寄生レベルがある程度深 くなると, 計算速度は速くなるが, 一方で寄生フィル タの係数の数は少なくなり, 寄生フィルタに対応する RMW の形状が崩れて検出精度が落ちることもある.

ここで寄生レベルを定めるために，寄生フィルタで は表されない RMW の部分を，RMW のエネルギー損 失 $L_{e}$ として次式 (14) により定義する.

$$
L_{e}=10 \log _{10}\left(\frac{\sum_{j} \sum_{k}\left(d_{j, k}\right)^{2}}{\|\psi(t)\|^{2}}\right)
$$

ただし式 (14)の $d_{j, k}$ は，4.2 節の手法 1 . を実行した 場合のウェーブレット係数 $d_{j, k}$ であり，これらは寄生 レベルの係数 $c_{j-1, k}$ には反映されない損失成分と考え ることができる.ここで式 (13) の第 3 項目の周波数 を $200[\mathrm{~Hz}]$ から $600[\mathrm{~Hz}]$ まで $50[\mathrm{~Hz}]$ 間隔で変化させ たものをモデル信号として，第 2 章で示した手法で SC-RMW を構成した. ただしサンプリング周波数を $3500[\mathrm{~Hz}], \mathrm{RMW}$ 長を 512 点とした. さらにウェーブ レットSymlet5 をべース MW に用いて，RMW を固定 されたレベル -2 まで分解し, 4.2 節で示した手法で RMW に対応する寄生フィルタを設計するとともに, $x_{\text {out }}$ も求めた. それと同時に, この時のウェーブレッ 卜係数 $d_{j, k}$ から式(14)により $L_{e}$ を計算した.

図 6 には RMW の実数部と $x_{o u t}^{R}$ の形状の例を示

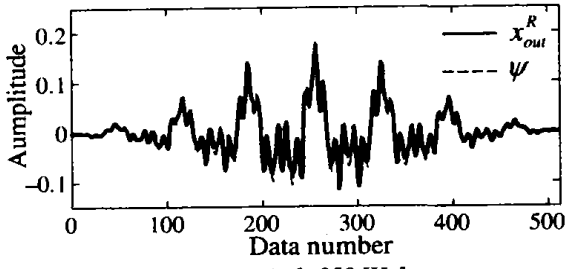

(a) $f=350[\mathrm{~Hz}]$

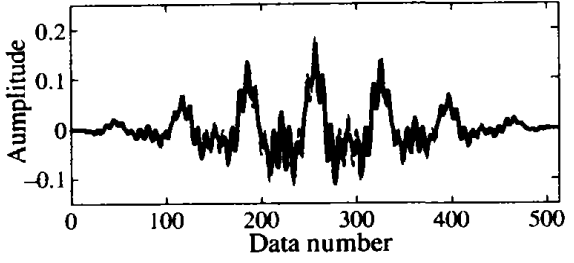

(b) $f=400[\mathrm{~Hz}]$

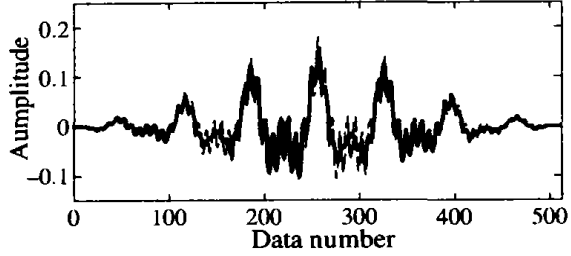

(c) $f=450[\mathrm{~Hz}]$

Fig. 6 Shapes of the RMW $\psi(t)$ and $\left\{x_{o u t, k}^{R}\right\}$

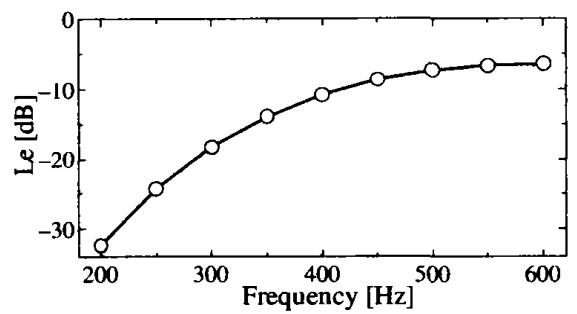

Fig. 7 Power loss $L_{e}$ that calculating by Eq.(14)

す. ただし図 6(a) は式 (13) の第 3 項目の周波数 $f=$ $350[\mathrm{~Hz}]$ の場合であり, (b) は $f=400[\mathrm{~Hz}]$, (c) は $f=$ $450[\mathrm{~Hz}]$ の場合である. また図 7 には各凬波数 $f$ に対 応する $L_{e}$ の変化を示している. 図 6 と図 7 からわか るように, 周波数 $f=350[\mathrm{~Hz}]$ の場合に, RMW と $x_{\text {out }}^{R}$ との差は小さく, $L_{e^{*}}-14[\mathrm{~dB}]$ である. 周波数 $f$ が大 きくなるにつれて RMW と $x_{\text {out }}^{R}$ との差は次第に大きく なり, 周波数 $f=450[\mathrm{~Hz}]$ の場合に RMW の形状は崩 れ, $L_{e}=-8.64[\mathrm{~dB}]$ となった.

この現象は図 5 から説明できる. すなわち周波数 $f$ が大きくなるにつれて， RMW の周波数 $f$ の成分は DWT の分解フィルタの減褒領域にまで達し，そのエ ネルギーが損失してしまい, 寄生フィルタを RMWに 近似できなくなる，従って寄生フィルタを RMW に精 度良く近似するためには，RMW のエネルギ一損失 $L_{e}$ を小さくする必要がある.ここで図 6 と図 7 の結果か 5, 条件 : $L_{e} \leqq-15[\mathrm{~dB}]$ を満足するレベルを寄生レ ベルと設定することで，寄生フィルタを RMW へ良好 に近似できるものと考えられる.

ここで解析信号を寄生レベル $j$ にて解析する場合の 乗算回数を計算量 $Q_{j}$ (詳紏は 5.2 で述べる) とし, RMW 


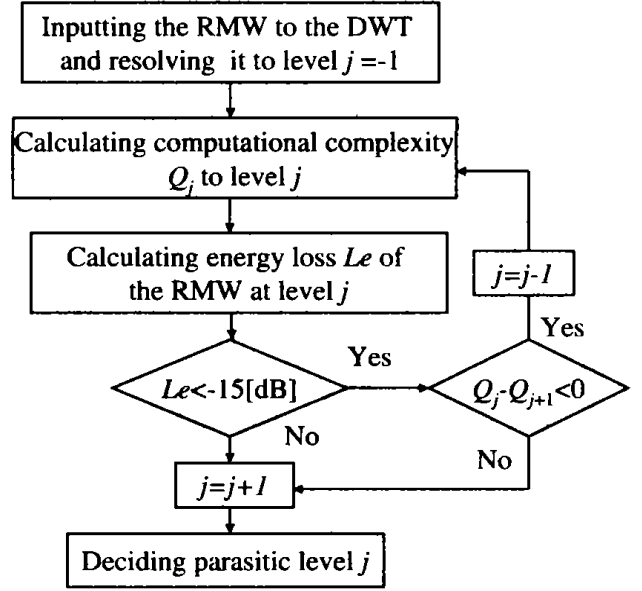

Fig. 8 Procedure of determining parasitic level

のエネルギー損失 $L_{e}$ と計算量 $Q_{j}$ を用いて，図 8 の手 順に従い，以下のように寄生レベルを決定する.

1. 異常信号から構成された RMW を解析信号として DWTに入力し，レベル $j=-1$ まで解析する.

2. レベル $j$ までの計算量 $Q_{j}$ を計算する.

3. レベル $j$ までの RMW のエネルギー損失 $L_{e}$ を計 算する.

4. 条件：Le $\leqq-15[\mathrm{~dB}]$ を満足するかどうかを検証 する.この条件を満たす場合には，1つ前の浅い レベルとの計算量の差 $Q_{j}-Q_{j+1}$ を求める. 計算 量が隇少していれば、レベル $j$ をさらに1つ深く $(j=j-1)$ 進め, 2. に戻って 2. から4.までを綝り 返して行う。計算量が増加していれば，レベル $j$ を1 つ浅く $(j=j+1)$ 戻り, そのレベルを寄生レ ベルとして出力する. 条件 : $L_{e} \leqq-15[\mathrm{~dB}]$ を満 さない場合にも，レベル $j$ を 1 つ浅く $(j=j+1)$ 戻り，そのレベルを寄生レベルとして出力する. このようにして定まった奇生レベルに寄生フィルタを 付与すれば，寄生フィルタによる RMW の良好な近似 が得られると考えられる。

\section{P-DWTによる高速ウェーブレット舜時相関}

5.1 高速ウェーブレット瞬時相関の定慗 ここ で, 異常信号の検出を定量化するために，高速ウェーブ レット瞬時相関 (Fast wavelet instantaneous correlation, F-WIC) を次式のように定義する.

$$
R(k)=\sqrt{\left(x_{k}^{R}\right)^{2}+\left(x_{k}^{I}\right)^{2}}
$$

ただし， $k$ は離散化時間であり，離散化間隔 $\Delta t$ は寄生 レベルによって異なり， $\Delta t=\Delta \tau / 2^{j}$ となる. また $\Delta \tau$ はサンプリング間隔である. すなわち $R(k)$ の時間間 隔 $\Delta t$ は寄生レベル $j$ が深くなるにつれ，CWT を用い るウェーブレット瞬時相関 $R(b)$ の時間間隔 $\Delta \tau$ より大

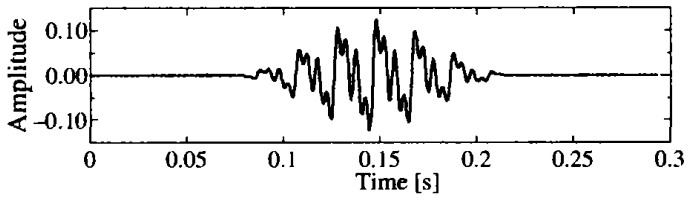

(a) Analysis signal

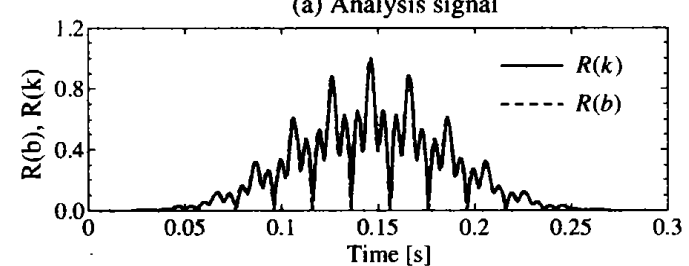

(b) $R(b)$ and $R(k)$

Fig. 9 Example of $R(k)$ obtained from the P-DWT and $R(b)$ obtained from the CWT

Table 2 Number of multiplication

\begin{tabular}{|c|c|c|c|c|c|}
\hline & \multicolumn{5}{|c|}{ RMW length } \\
\hline level & 64 & 128 & 256 & 512 & 1024 \\
\hline \hline-1 & 78 & 142 & 270 & 526 & 1038 \\
\hline-2 & 66 & 98 & 162 & 290 & 546 \\
\hline-3 & 90 & 106 & 138 & 202 & 330 \\
\hline-4 & 162 & 170 & 186 & 218 & 282 \\
\hline \hline CWT & 138 & 260 & 516 & 1028 & 2052 \\
\hline
\end{tabular}

きくなる.これに対応して $R(k)$ の計算量が減り高速 化が実現される. また実部 $x_{k}^{R}$ と虚部 $x_{k}^{I}$ を用いること で, $R(k)$ は解析信号と寄生フィルタの間に生じる位相 の影響を抑えることができる.

ここで, 図 4(a) に示した寄生フィルタ $\left\{u_{k}^{I}\right\}$ と $\left\{u_{k}^{R}\right\}$ を用い，図 4(b) に示した RMW の虚数部を解析信号と して上述の手順より $R(k)$ を求めた. この時の寄生フィ ルタによる RMW のエネルギー損失 $L_{e}$ は $-32[\mathrm{~dB}]$ であ る. また比較のために RMW の実数部と虚数部 (図 4(b) には虚数部のみを表示）を用いて同様の解析信号を解 析して, CWTによる $R(b)$ を求めた. それらの結果を 図 9 に示す. ただし図 9(a) は解析信号で, (b) は求め られた $R(k)$ と $R(b)$ である. 図 9(b) に示した $R(k)$ と $R(b)$ を比較してわかるように, $R(k)$ と $R(b)$ の振幅の 大きさと振幅の時刻はよく一致している．ここで $R(k)$ と $R(b)$ の差を評価するために, $\Sigma|R(k)-R(b)|^{2} / N$ で表 される平均二乗誤差 (MSE) を定義して求めたところ, $-69.4251[\mathrm{~dB}]$ となった. すなわち本研究で提案した P-DWTによる F-WIC は, 寄生フィルタ $\left\{u_{k}^{R}\right\} と\left\{u_{k}^{I}\right\}$ の設計が良好であれば，元の RMW を用いた CWT に よる WIC と，ほぼ同様の検出精度を持つと言える。

5.2 計算量の比較 F-WIC による異常信号検出 は，実時間で行うことを想定している.ここで $R(k)$ を 1 サンプル得るための乗算回数を計算量の目安として 


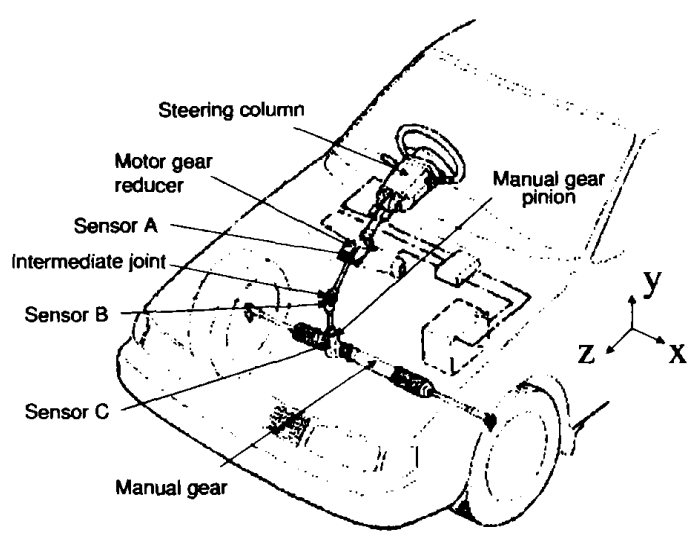

Fig. 10 Steering system with the EPS and experimental setup, where sensors $A, B, C$ are 3-dimensional acceleration sensors ${ }^{(5)}$

次式で定義する.

$$
Q_{j}=10 \sum_{i=p}^{-1} 2^{i+1}+2^{p+1} L+4
$$

ただし $p$ ( $p<0$ : 整数) は寄生レベル， $L$ は RMW の 長さである. また式 (16) の第 1 項目は DWT, 2 項目 は寄生フィルタ, 3 項目は F-WIC による乗算回数であ る. また比較のために, CWT による WIC の計算量も 次に示す.

$$
Q_{j}=2 L+4
$$

表 2 にはP-DWT による F-WIC の計算量と，CWT に よる WIC の計算量を示す．表 2 が示すように, RMW の長さが長く, 寄生レベルが染くなるほど, WICに 対して F-WIC の計算量がより小さくなる傾向にある. これは P-DWT がダウンサンプリングを有効に利用し， 計算量を減少させる方向に働くためである．しかし奇 生レベルが下げすぎると P-DWT の計算量が再び堌加 していく現象が見られる.これは, 寄生レベルを下げ たことによる寄生フィルタの計算量の減少よりも，そ れによって付加される DWT の計算量のほうが大きく なるためである. 従って 4.3 節におるおる寄生レベルの 決定には，計算量を最小にする工夫を施している。

\section{F-WIC の異常音源検出への応用}

近年, 多くの車のステアリング操作機構には図 10 に示されるような電動パワーステアリング (Electric Power Steer-ing, EPS) が採用されている.しかし，モー ターや減速機は車室内にあり, 特に悪路を走行する際 に車室内でラトル音という騒音が発生し, 問題となっ ている，そのため，ラトル音を低減するにはまず音源 を特定しなければならないが，悪路を走行する際に モータギヤリデューサ (MGR), インタミジョイント (ITJ), マニュアルギヤ (MNG) などのステアリング操

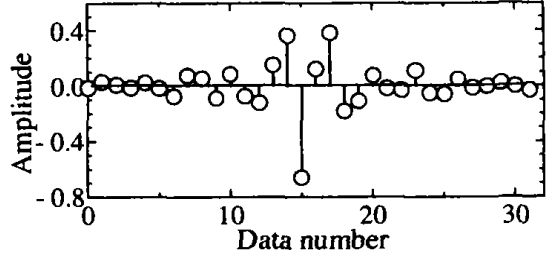

(a) $\left\{u_{k}^{R}\right\}$ of rattle noise

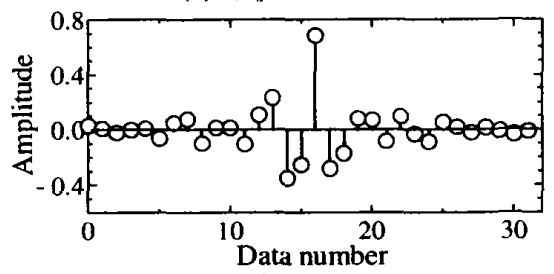

(b) $\left\{u_{k}^{l}\right\}$ of rattle noise

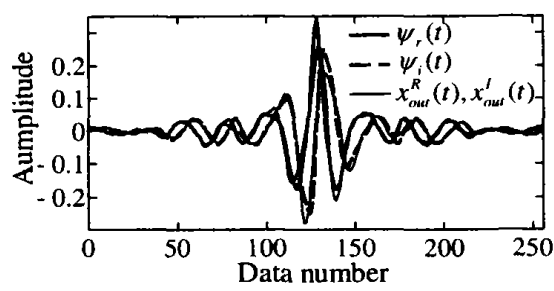

(c) RMW and $x_{\text {out }}^{R}(t), x_{\text {out }}^{t}(t)$

Fig. 11 Example of the parasitic filters $\left\{u_{k}^{R}\right\},\left\{u_{k}^{I}\right\}$ designed from the A-RMW of rattle noises and the A-RMW

作機構の各部分が振動し, その中でどの部分の振動が ラトル音の音源であるかを特定することは非常に困難 である.この問題に対して，著者らは 8 つのラトル 音から A-RMW を構成し，それを用いた CWT による WIC $R(b)$ を用いて異常信号を検出し，その有効性を確 認した ${ }^{(5)}$. 本論文では提案したP-DWTによる F-WIC を用い，ラトル音の望源探查の高速化を図る.

実験は実車で行った. ステアリング操作機構の各部 分の振動を計るために，図 10 に示すように，3つの 3 方向加速度センサ A, B, C をそれぞれ MGR, ITJ, マ ニュアルギヤピニオンに取り付けた. ただし，センサの 3 方向については, $x$ 方向は車の横方向, $y$ は上下方向, $z$ は進行 (前後) 方向と定めた. また車室内で騒音を計 るためにドライバの足元にマイクを取り付けた. ここ で 8つのラトル音から構成された A-RMW $(L=256)$ を, DWT によりレベル毎に分解して $L_{e}$ と $Q_{j}$ を評価する ことにより, 寄生レベルは $-3\left(L_{e}=-31[\mathrm{~dB}], Q_{j}=138\right)$ が適当であると判断した．次に構成された RMW よ り設計されたラトル音の寄生フィルタを図 11 に示す. 図 11(a) は設計された秦生フィルタの实数部 $\left\{u_{k}^{R}\right\}$ ，(b) は虚数部 $\left\{u_{k}^{l}\right\},(\mathrm{c})$ は RMW の $\psi_{r}(t), \psi_{i}(t)$ の波形と, 寄生フィルタの $x_{\text {out }}^{R}(t), x_{\text {out }}^{l}(t)$ の波形である. 図 $11(\mathrm{c})$ に示すように, $\psi_{r}(t), \psi_{i}(t)$ と $x_{\text {out }}^{R}(t), x_{\text {out }}^{I}(t)$ はほぼ完全 に重なっており，寄生フィルタが RMW に良く近似し ていることが分かる. 


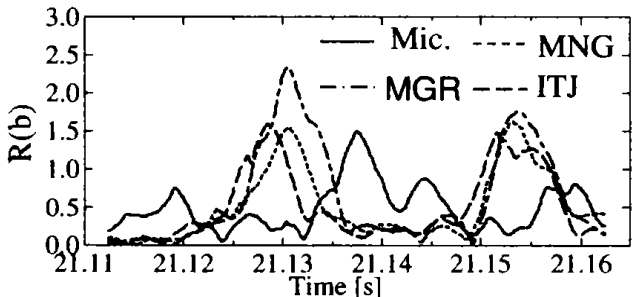

(a) $R(b)$ obtained by CWT

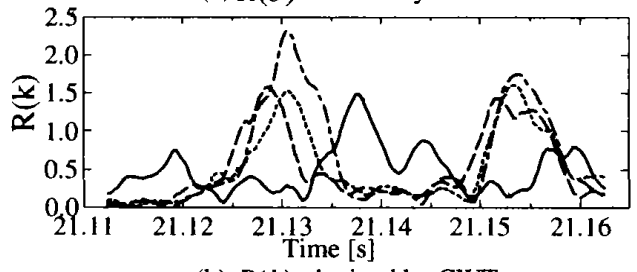

(b) $R(k)$ obtained by CWT

Fig. 12 Rattle noise source detection results obtained from $R(b)$ by using the CWT and $R(k)$ by using the P-DWT

穾車で計測された $z$ 方向の振動信号に対して，ラト ル音の A-RMW を用いた CWT により得られた $R(b)$ の例を図 12(a)に, 図 11 に示した寄生フィルタを用 いたP-DWT により得られた $R(k)$ の例を $(\mathrm{b})$ に示す. 図 12(a)に打けるR(b)のピークにより, MGRの振動は ラトル音に大きく寄与することが分かる．音声の $R(b)$ ピークは MGR の $R(b)$ ピークより遅くなり, 遅れ時 間は平均的に約 0.0065 [s] となる. この現象を確認す るために，ハンマリングで MGR を加振する際のラト ル音を解析した結果，連転席側ピラーの付近からのラ トル音（固体伝播音）が大きいことがわかった. そし て，ハンマリングで MGR を加振する際に MGR の振 動が運転席側ピラーに伝達する様子を調べた結果, 運 転席側ピラーの振動は振動源に対する時間遅れが存在 し, 約 0.003-0.004[s] となった. また運転席側ピラー から耳位置までの距離が約 1 [m] である. 仮にラトル 音は運転席側ピラーから耳位置まで伝達するために約 0.003 [s]（音速 340[m/s]） かかるとすると, 加振位置 から耳元までの時間は約 0.006-0.007[s] となる.すな わち, 実際の振動と音の伝達を考えると, $0.0065[\mathrm{~s}]$ と いう時閵遅れは妥当である. また $R(b)$ のピークのタ イミングを比べると，ITJ の $R(b)$ のピークの位置は MGR の $R(b)$ のピークの前にある. タイヤからの $z$ 方 向の振動がハンドルへ伝えてくる順番から考えると， ITJ のところでラトル音に寄与する成分が存在し，そ の成分は MGR の振動に寄与している. 以上の解析結 果は熟練技術者の判定結果とよく一致している.

さらに図 12(b) の $R(k)$ と (a) の $R(b)$ の平 均 2 乗誤差を求めたところ, MNG の場合には $\mathrm{MSE}=-39.5[\mathrm{~dB}]$, ITJ の場合には $\mathrm{MSE}=-38.6[\mathrm{~dB}]$, MGR の場合には MSE=-38.1[dB] であった.また，
CPU:2.0[GHz],RAM:1.0[GB],ソフトウェア:LabVIEW ver8.5(National Instruments 社) を使用した計算条件に おいて，1 サンプルの計算時間は P-DWT による F-WIC が $5.10 \times 10^{-7}[s]$, CWT による WIC が $1.15 \times 10^{-6}[s]$ と なり，F-WICの方は WICより約 2.3 倍速くなった. す なわち P-DWT は計算精度を保持しながら F-WIC の 高速化を実現した。

\section{7. とめ}

本研究では, 異常信号検出の高速化のために PDWT を提案し，それによる F-WICを車の異常音源探 査に適用してその有用性を確認した，得られた主な結 果は以下のと扔りである。

1. P-DWT は従来 DWT に寄生フィルタを付与させ ることにより実現される. 本論文に示した手法に より寄生レベルを定め, 寄生フィルタを設計すれ ば，駦生フィルタは従来の DWT の計算に影響を 与えずに異常信号の検出ができる.

2. P-DWT のための寄生フィルタの新たな喑計法は シンプルで有効であることが確認できた.

3. 実用例において, P-DWTによる高速ウェーブレッ 卜瞬時相関 (F-WIC) は, 従来の CWT による WIC の 2.3 倍の計算の高速化を実現した.

4.P-DWT を用いた F-WIC をラトル音音源探査に適 用し，その有効性を示した。

今後, 本手法をさまざまな分野の非定常信号の検出に 応用していくことを計画している.

\section{文献}

(1) Allen, R.L. and Mills, D.W., Signal Analysis, IEEE Press(2004), P.712.

(2) Daubechies, I., Ten lectures on wavelets, SIAM, Philadelphia(1992).

(3) Ishimitsu, S., Kitagawa, H., Horihata, S., Active control of the room noise of ship by the correction analysis of measured wavelet, Proc. of inter.noise, Vol.3(2000), pp.1768-1771.

(4) Zhang, Z., Horihata, S., Miyake, T. and TOMITA, E., Knocking detection by complex wavelet instantaneous correlation, Proc. of the 13th Inter. Pacific conf. on automotive engineering(2005), pp.138-143.

(5) Zhang, Z., Ikeuchi, H., Ishii, H., Horihata, H., Imamura, T. and Miyake, T., Real signal mother wavelet and its application on detection of abnormal signal: Designing average complex real signal mother wavelet and its application, Transactions of the JSME C, Vol.73, No.730(2007), pp.1676-1683.

(6) Mallat, S.G., a wavelet tour of signal processing, Academic Press( 1999), p.255.

(7) Sweldens, W., The lifting scheme: A construction of second generation wavelets, SIAM Journal on Mathematical Analysis, Vol.29, No.2(1998), pp.511-546. 